\title{
ANALYSIS OF BAKERY PROPERTIES OF GRAIN OF NEW VARIETIES AND LINES OF WHEAT SPELTS
}

\author{
Nina Osokina \\ Department of technology of storage and processing of grain \\ Uman National University of Horticulture \\ 1 Instytutska str., Uman, Ukraine, 20305 \\ ninaosokina1953@gmail.com \\ Vitalii Liubych \\ Department of technology of storage and processing of grain \\ Uman National University of Horticulture \\ 1 Instytutska str., Uman, Ukraine, 20305 \\ LyubichV@gmail.com \\ Larysa Novak \\ Department of technology of storage and processing of grain \\ Uman National University of Horticulture \\ 1 Instytutska str., Uman, Ukraine, 20305 \\ lnovak590@gmail.com \\ Tetiana Pushkarova-Bezdil \\ Department of technology of storage and processing of grain \\ Uman National University of Horticulture \\ 1 Instytutska str., Uman, Ukraine, 20305 \\ taniaviolaarvens@gmail.com \\ Olesia Priss \\ Department of Technology of Processing and Storage of Agricultural Products \\ Tavria State Agrotechnological University \\ 18 B. Khmelnitsky ave., Melitopol, Ukraine, 72310 \\ olesyapriss@gmail.com \\ Valentyna Verkholantseva \\ Department of Technology of Processing and Storage of Agricultural Products \\ Tavria State Agrotechnological University \\ 18 B. Khmelnitsky ave., Melitopol, Ukraine, 72310 \\ wer.valentina@gmail.com \\ Olena Hryhorenko \\ Department of Technology of Processing and Storage of Agricultural Products \\ Tavria State Agrotechnological University \\ 18 B. Khmelnitsky ave., Melitopol, Ukraine, 72310 \\ grigalena@ukr.net \\ Volodumur Pusik \\ Department of Agrotechnology and Ecology \\ Kharkiv Petro Vasylenko National Technical University of Agriculture \\ 44 Artema str., Kharkiv, Ukraine, 61002 \\ PusikV@gmail.com \\ Ludmila Pusik \\ Department of Agrotechnology and Ecology \\ Kharkiv Petro Vasylenko National Technical University of Agriculture \\ 44 Artema str., Kharkiv, Ukraine, 61002 \\ Ludmilap@gmail.com
}

Abstract

There were studied technological properties of grain of different varieties and lines of wheat spelt. There were analyzed differences between the quality of bread of flour of the highest sort and wholemeal, demonstrated the topicality of the differentiated 
approach to technological properties of flour for its production, elucidated the possibility of using wholemeal of wheat spelt for producing bread of the increased biological value.

It was experimentally confirmed that a value of gloss of the bread surface and its general assessment is influenced by the protein content in grain. The gluten content influences bread quality parameters a bit less. At the same time, the index of gluten deformation also influences the crust surface, size of pores, general assessment of the bread quality. Its quality is high in all studied samples. The highest general culinary mark is put to bread, obtained from flour of the variety Zorya of Ukraine, LPP 3132, lines NAK34/12-2 and TV 1100.

Based on studied of organoleptic, physical-chemical parameters of bread, there was confirmed the possibility of the promising use of wheat spelt grain in the bakery technology for raising the quality of products and widening the assortment.

Keywords: wheat spelt, bakery properties, bread quality, flour of the highest sort, wholemeal.

(C) Nina Osokina, Vitalii Liubych, Larysa Novak, Tetiana Pushkarova-Bezdil, Olesia Priss, Valentyna Verkholantseva,

DOI: $10.21303 / 2504-5695.2018 .00601$ Olena Hryhorenko, Volodumur Pusik, Ludmila Pusik

\section{Introduction}

Wheat spelt - is a high-protein plant with much more irreplaceable amino acids, comparing with soft wheat. Gluten of grain has much less expressed allergic properties. That is why the scientific substantiation of wheat spelt grain processing is urgent.

Technological properties of wheat grain depend on the content and properties of their main components and biochemical features. The most important quality parameter of grain quality is bakery properties. The technology of cooking dough of wheat spelt flour differs from the one for soft wheat, which starch grains are closely bound with the protein matrix. It decreases the attacking ability of starch by enzymes. That is why, fermentation of dough of wheat spelt is less long comparing with soft wheat [1].

The culinary assessment of bread depends on the protein content, gluten, gas-retaining power of dough and carbohydrate-amylase complex [2]. That is why, fermentation of dough of wheat spelt is less long comparing with soft wheat [3]. At the same time $20 \%$ less carbon dioxide is created at fermentation [4]. Although studies of other scientists [5, 6] testify that bread of wheat spelt grain has a higher output volume, correct form, crumb color - cream, pleasant taste and smell. Crumb differs by the grainy and rough structure comparing with soft wheat. Products of flour of wheat spelt have crackling crust and dense crumb [7].

The aim of the study was to analyze bakery properties of grain of new varieties and lines of wheat spelt. It allows to widen the assortment and to raise the quality of bakery products.

\section{Materials and methods}

The study was conducted in the Uman National University of Horticulture (Ukraine) under conditions of the laboratory of the Department of technology of storage and processing of grain. Grain of 16 varieties and lines of wheat spelt were used.

They were planted under conditions of the Right-bank forest-steppe of Ukraine. In studied samples there were determined the content of protein, gluten, falling number, gluten deformation index, gas-retaining power, volume and quality of bread. The analysis of grain of wheat and bread was realized with exactness and logic successiveness, according to methods, described in standards SSU 4117-2007, SSU 21415-1:2005, SS 30498-97 and conventional methods [8-11].

The experimental part of the work was realized at the laboratory of the Department of technology of storage and processing of grain of the Uman National University of Horticulture (Ukraine). There were used grain of wheat spelt varieties - Schwabenkorn (Austria), NSS 6/01 (Serbia), Sweden 1 (Sweden). Lines, obtained by hybridization Tr. aestivum/Tr. spelta - LPP 1197, LPP 3117, LPP 1304, LPP 1224, LPP 3122/2, P 3, LPP 3132, LPP 3373, LPP 1221. Lines NAK 34/12-2 and NAK 22/12, obtained by hybridization Tr. aestivum/amphiploid (Tr. durum/Ae. tauschii). Line TV 1100, obtained by hybridization Tr. aestivum (variety Kharkivska 26)/Tr. kiharae, with selecting the winter forms. Grains of Ukrainian varieties and lines were insufficiently analyzed by scientists by main bakery properties, so they were included in the study. Grain was planted under 
conditions of the Right-bank forest-steppe of Ukraine. The control (standard) was a zoned wheat variety Zorya of Ukraine (st), most spread under conditions of Ukrainian production [8].

The protein content was determined by SSU 4117-2007, gluten SSU 21415-1:2005, falling number - by SSU 30498-97. The index of gluten deformation - by MGD-7 (Fig. 1), flour strength - by the dough pellet stability in water. The gas-restraining power - by the conventional methodology by changing the dough volume in a measuring cylinder at temperature $30{ }^{\circ} \mathrm{C}$, air relative humidity $75 \%$ in the thermostat up to the moment of its loss. The dough humidity $60 \%$, blending was conducted using $1 \%$-solution of yeast suspension [9].

The volume and quality of bread were assessed and determined by the methodology of variety-testing of Ukraine [10].

The average mark in points was determined as an arithmetical mean value by all parameters - by Azzi method of relative values, where the most value of each parameter was considered as $100 \%$ [11].

For assessing the density of connection between parameters, there was used R. E. Chaddock scale [12], that is weak at correlation coefficient value $0,1-0,3,0,3-0,5$ - moderate, $0,5-0,7$ - essential, $0,7-0,9$ - high, 0,9-0,99 - very high. The mathematical processing of data was conducted by the method of one-factor dispersion analysis [13].

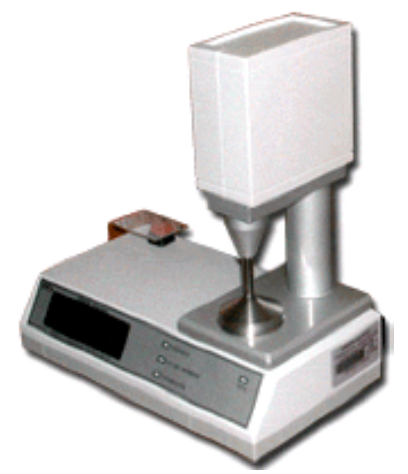

Fig. 1. Photo of the measurer of gluten deformation MGD-7 (produced by Ukraine)

\section{Results}

The index of gluten deformation influenced the form and quality of bread (Fig. 2, 3).

Among the studied forms of wheat spelt, the high volume of bread of flour of the highest sort was inherent to the variety Zorya of Ukraine and line NAK34/12-2, middle indices were observed in the variety Sweden 1 and lines LPP 3132, LPP 3117, low volume of bread, comparing to the standard was inherent to the variety NSS 6/01, lines LPP 1197, LPP 3373 and TV 1100.

The volume of bread of wholemeal (Fig. 2) was by 10-20\% less comparing with one of bread, obtained from flour of the highest sort. The middle volume of bread was obtained from wholemeal of the variety Zorya of Ukraine, low - from flour of the variety Sweden 1 and lines LPP 3132, LPP 3117, TV 1100. These indices were very low in the rest of forms.

The relief of formed bread of flour of the highest sort was the highest in the wheat spelt variety Zorya of Ukraine and line NAK 34/12-2, middle indices - in varieties Sweden 1 and five lines. The index of bread relief was essentially less in the rest of studied forms comparing with the control.

The relief index of bread of wholemeal in the wheat variety Sweden 1 and five lines didn't exceed the standard. It was essentially less in the rest of forms and lines comparing with the control.

The assessment of the surface of bread, obtained of flour of the highest sorts of different wheat spelt varieties, was realized according to the following parameters: color of crust, surface of crust, size of the gloss surface.

According to the bread crust color parameter, all studied varieties and lines had 9 points (Fig. 2, 3). The bread crust surface in the variety Sweden 1 and lines LPP 3117, LPP 3122/2, P 3, LPP 3132, NAK34/12-2 was assessed as 9 points. The wheat spelt variety, taken as a standard and 
rest of varieties and lines had 7 points. Gloss took the whole surface of bread of flour of the varieties Zorya of Ukraine, Schwabenkorn, lines LPP 3373, LPP 1221, NAK 22/12, TV 1100 had the mark as 9 points. Bread, obtained from the lines LPP 1304, LPP 1224, P 3, LPP 3132, gloss took only $50 \%$, and in the rest of forms $-25 \%$ of crust surface.

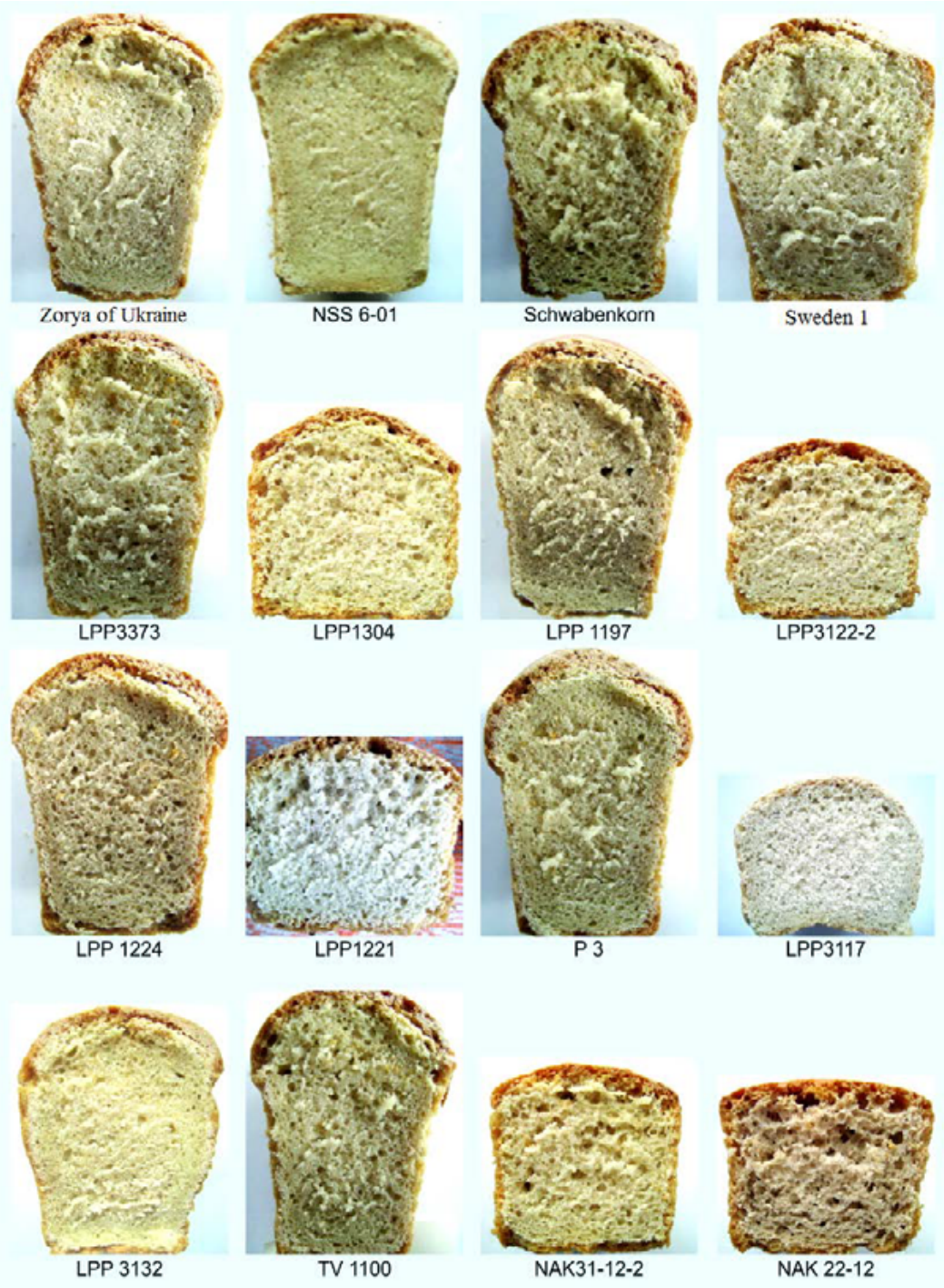

Fig. 2. Photo of formed bread of flour of the highest sort of different varieties and lines of wheat spelt

Elasticity, smell, taste, size of pores, evenness of their distribution, consistence at chewing crumb was very high as 9 points, not depending on a variety and line, but the rest of parameters essentially changed. Thus, 9-point mark by the crumb color was inherent to bread of flour, lines LPP 1197, LPP 1224, NAK34/12-2, NAK 22/12 and variety Schwabenkorn. Crumb of bread of flour of variety NSS 6/01 and line LPP 3132 was light with the yellow tint -6 points. The rest of studied forms had the light-yellow one, corresponded to 5 points.

Forms of wheat spelt differed by the parameter of crumb pores' size. Thus, bread of flour Sweden 1 and lines LPP 3117, LPP 3122/2, P 3, LPP 3132, NAK34/12-2 had fine pores with thin walls, middle thick-walls were $25 \%$ in them, that corresponded to 7 points. The index, corresponded to 5 points (number of middle thick-wall pores was $50 \%$ ) was detected in the varieties Zorya of Ukraine and Schwabenkorn and lines LPP 1224, LPP 3373, LPP 1221, TV 1100. The rest of numbers had the worst mark of bread pores' sizes as 3 points. 
The general mark of the quality of bread of flour of the highest sort was very high in three varieties and eight lines of wheat spelt $-8,0-8,4$ points or $89-93 \%$ of the maximal value. Less values were observed in the lines LPP 1197, LPP 3117, LPP 3122/2 - 7,6-7,8. The mark of bread of the variety NSS 6/01 and line LPP 1304 was 7,2-7,4 points, essentially lower than the standard index, but remained high.

The index of the crumb surface of bread of flour of the variety Sweden 1 and lines LPP 3117 , LPP 3122/2, P 3, LPP 3132, NAK34/12-2 was the highest as 9 points. The bread surface of flour of the rest of varieties and lines was rather even, with separate bubbles and cracks that didn't pass along the whole surface ( 7 points).

Such parameters as elasticity, smell, taste, evenness of pores distribution in bread, baked of wholemeal of the studied varieties and lines were the highest as 9 points.

Pore sizes of bread, baked of wholemeal of wheat spelt of the varieties Sweden 1 and five lines (LPP 3117, LPP 3122/2, P 3, LPP 3132, NAK34/12-2) were as 9 points. In the rest of bread samples this index was 7 points.

The general mark of the quality of bread of wholemeal was very high - from 8,3 to 9,0 points. The highest quality was inherent to bread of flour of the varieties Sweden 1 and lines LPP 3117, LPP 3122/2, P 3, LPP 3132, NAK34/12-2 - 9,0 points, and in the rest of samples it was less by $8 \%$.

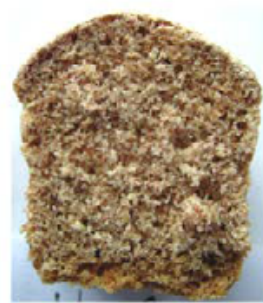

Zorya of Ukraine

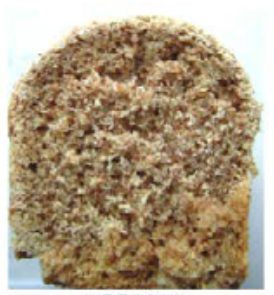

LPP3373

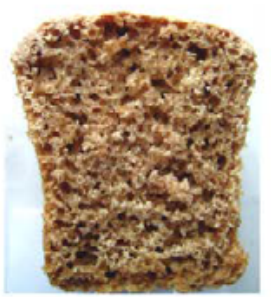

IPP 1224

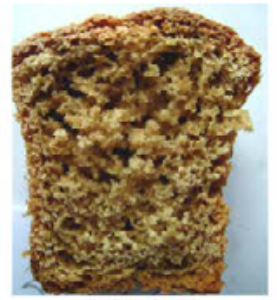

LPP 3132

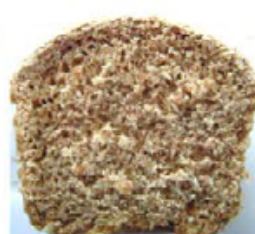

NSS 6-01

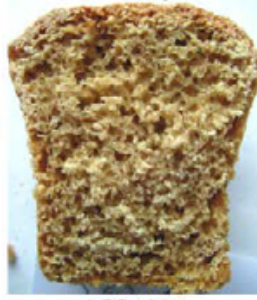

LPP1304
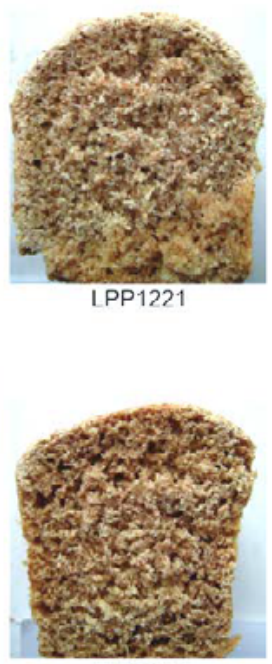

TV 1100

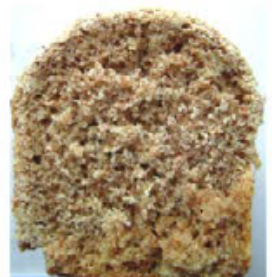

Schwabenkorn

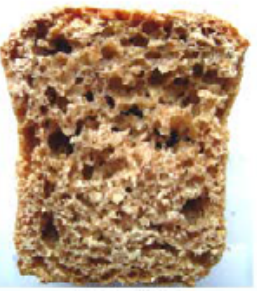

LPP 1197

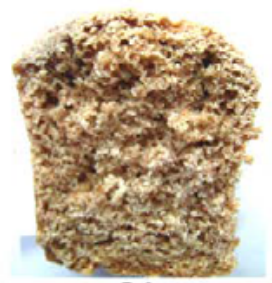

P 3

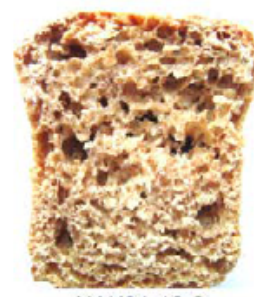

NAK31-12-2

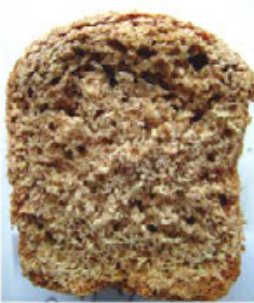

Sweden 1

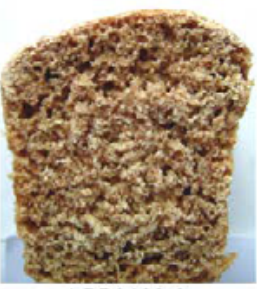

LPP3122-2

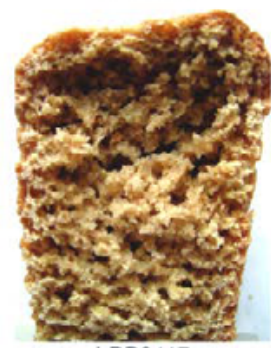

LPP3117

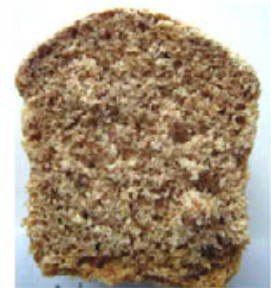

NAK 22-12

Fig. 3. Photo of formed bread of wholemeal of different varieties and lines of wheat spelt 


\section{Conclusions}

Bakery properties of grain depend on the variety and line of wheat spelt, because different genotypes have the specific ability to form protein-proteinase and carbohydrate-amylase complexes.

Bread of wheat spelt grain has the low volume -303 to $523 \mathrm{~cm}^{3}$ of flour of the highest sort $1,0-7,6$ points and $270-470 \mathrm{~cm}^{3}$ of wholemeal depending on genotype. Its general culinary quality is high - 7,2-8,4 and 9,3-9,0 points, respectively. The highest general culinary mark is inherent to bread of flour of the variety Zorya of Ukraine, lines LPP 3132, NAK34/12-2 and TV 1100.

The volume of gloss of the bread surface and its general mark mostly depend on the protein content in grain. These bread quality parameters less depend on the gluten content. At the same time the crust surface, pores size, general mark of the bread quality depends on the gluten deformation index.

The advantages of the study are the use of the established peculiarities of bakery properties of wheat spelt grain at bakery enterprises. At that, there were elucidated the possibility of using wholemeal of wheat spelt for baking bread of the increased biological value.

The use of the system approach for assessing grain of the studied varieties and lines of wheat spelt allowed to decrease the number of parameters for determining their suitability for bakery goals up to three ones (content of protein and gluten, deformation index), because the high correlation is set between these parameters and quality of the ready product.

The further promising directions of the research are the analysis of the suitability of wheat spelt flour for producing confectionary, macaroni, peeled grain, dry breakfasts, especially of wholemeal.

But the synthesis of new genotypes of wheat spelt, especially introgression of genes from remote forms can change the influence of bakery properties on the quality of ready products that is a weak side of the conducted studies.

\section{References}

[1] Demirkesen, I., Mert, B., Sumnu, G., Sahin, S. (2010). Rheological properties of gluten-free bread formulations. Journal of Food Engineering, 96 (2), 295-303. doi: 10.1016/j.jfoodeng.2009.08.004

[2] Arufe, S., Chiron, H., Dore, J., Savary-Auzeloux, I., Saulnier, L., Della Valle, G. (2017). Processing \& rheological properties of wheat flour dough and bread containing high levels of soluble dietary fibres blends. Food Research International, 97, 123-132. doi: 10.1016/j.foodres.2017.03.040

[3] Podpriatov, G., Skaletska, L., Nasikovsky, V. (2011). Interdependence of technological indicators of wheat grain quality in the process of long-term storage. Scientific Bulletin of National University of Bioresources and Nature Management of Ukraine, 162 (1), 281-290.

[4] Bakare, A. H., Osundahunsi, O. F., Olusanya, J. O. (2015). Rheological, baking, and sensory properties of composite bread dough with breadfruit (Artocarpus communisForst) and wheat flours. Food Science \& Nutrition, 4 (4), 573-587. doi: 10.1002/fsn3.321

[5] Lozinska, T. (2013). Formation of the elements the productivity of new varieties of spring bread wheat in Forest steppe of Ukraine. Agrobiology, 10, 22-25.

[6] Ramya, P., Chaubal, A., Kulkarni, K., Gupta, L., Kadoo, N., Dhaliwal, H. S. et. al. (2010). QTL mapping of 1000-kernel weight, kernel length, and kernel width in bread wheat (Triticum aestivum L.). Journal of Applied Genetics, 51 (4), 421-429. doi: 10.1007/bf03208872

[7] Carlsen, M. H., Halvorsen, B. L., Holte, K., Bohn, S. K., Dragland, S., Sampson, L. et. al. (2010). The total antioxidant content of more than 3100 foods, beverages, spices, herbs and supplements used worldwide. Nutrition Journal, 9 (1). doi: 10.1186/1475-2891-9-3

[8] State register of plant varieties suitable for dissemination in Ukraine (2017). Kyiv, 32.

[9] Hospodarenko, H., Kostohryz, P., Liubych, V., Parii, F., Poltoretskyi, S., Polianetska, I., Riabovol, L. et. al.; Hospodarenko, H. (Ed.) (2016). Triticum spelta. Kyiv: LLC Juice group of Ukraine, 294.

[10] Tkachyk, S. (Ed.) (2015). Methodology of state scientific and technical examination of plant varieties. Methods of determining the quality indicators of crop production. Vinnytsia: Nilan-LTD, 160.

[11] Azzi, J. (1959). Agricultural ecology. Moscow: Foreign Literature Publishing House, 480.

[12] Chaddock, R. (1952). Exercises in statistical methods. Houghton, 166.

[13] Yeshchenko, V., Kopytko, P., Opryshko, V., Kostogryz, P.; Yeshchenko, V. (Ed.) (2005). Fundamentals of research in agronomy. Kyiv, 287. 